Optimalan način sjetve pšenice (Triticum aestivum L.) za uzgoj pšenične trave

Optimal method of sowing wheat (Triticum aestivum L.) for growing wheatgrass

Grubišić. S., Orkić, V., Guberac, S., Petrović, S., Lisjak, M., Kristić, M., Rebekić, A.

Poljoprivreda/Agriculture

ISSN: $1848-8080$ (Online)

ISSN: 1330-7142 (Print)

http://dx.doi.org/10.18047/poljo.25.2.5

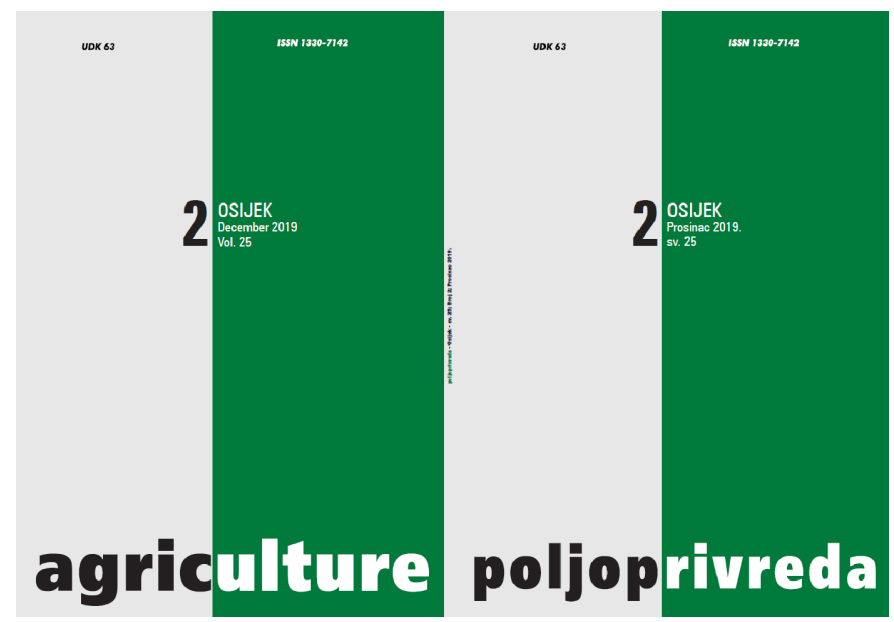

Fakultet agrobiotehničkih znanosti Osijek, Poljoprivredni institut Osijek

Faculty of Agrobiotechnical Sciences Osijek, Agricultural Institute Osijek 
ISSN 1330-7142

$U D K=633.11: 631.53 .04$

DOI: $10.18047 /$ poljo.25.2.5

\title{
OPTIMALAN NAČIN SJETVE PŠENICE (Triticum aestivum L.) ZA UZGOJ PŠENIČNE TRAVE
}

Grubišić. S., Orkić, V., Guberac, S., Petrović, S., Lisjak, M., Kristić, M., Rebekić, A.

Izvorni znanstveni članak

Original scientific paper

\begin{abstract}
SAŽETAK
Pšenična trava predstavlja biljke pšenice u ranim stadijima uzgoja prije ulaska u fazu vlatanja. Zbog visoke koncentracije minerala, vitamina, enzima, klorofila i bioflavonoida, pšenična trava se koristi kao prirodni dodatak prehrani. lako se može konzumirati u obliku praha i tableta, često se konzumira u obliku svježega soka, te ju stoga ljudi uzgajaju u kućanstvima. Veliki je problem u takvome uzgoju pojava i razvoj plijesni na supstratu i biljkama. Cilj istraživanja bio je ispitati razlike između površinske dezinfekcije sjemena te vrste i dezinfekcije podloge (bez podloge, kvarcni pijesak [dezinficiran i nedezinficiran] i Brillov supstrat [dezinficiran i nedezinficiran]) na pojavu plijesni, broj i masu biljaka (g) $i$ količinu dobivenoga soka (ml) u dvije sorte pšenice (Ilirija i Katarina). Metode površinske dezinfekcije sjemena i dezinfekcije supstrata, koje su ispitivane u provedenome istraživanju, moguće je primijeniti u kućanstvu. Najveći broj biljaka i masa biljaka utvrđene su na Brill supstratu, neovisno o sorti. Između mase biljaka i količine dobivenoga soka utvrđena je pozitivna korelacija $(r=0,98 ; p<0,01)$. Prosječna količina soka za

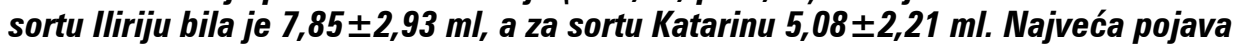
i razvoj plijesni utvrđeni su pri uzgoju pšenične trave bez podloge. Na ispitivane parametre najveći utjecaj imali su sorta i podloga.
\end{abstract}

Ključne riječi: pšenična trava, dezinfekcija sjemena, uvjeti uzgoja

UVOD

Pšenična trava predstavlja mlade izdanke pšenice (Triticum aestivum L.) koji se zbog svoje visoke nutritivne vrijednosti koriste kao prirodni dodatak prehrani ljudi. Prva istraživanja na pšeničnoj travi provedena su još 1932. godine, kada je američki agronom Charles F. Schnabel ispitivao utjecaj pšenične trave u hranidbi domaćih životinja, konkretno kokoši. Rezultati istraživanja su ukazali na to da su kokoši hranjene smjesom koja je sadržavala pšeničnu travu bile zdravije te su imale značajno bolju nosivost u zimskim mjesecima u odnosu na kokoši koje nisu hranjene dodatkom pšenične trave (Devi Sowjanya i sur., 2015.). Schnabel je bio zagovornik uzgoja pšenične trave na polju i konzumiranja dehidriranoga praha pripremljenog od listova pšenice, ubranih prije početka vlatanja. Držao je da je to najbolji način za uzgoj i pripremu pripravaka od pšenične trave. Za razliku od njega, Ann Wigmore (1909.-1996.) je razvila sustav uzgoja pšenične trave u kućanstvima i zagovarala korištenje svježega soka od pšenične trave u terapeutske svrhe (Wigmore, 1985.). Tijekom godina, utvrđeno je da pšenična trava sadrži mnoštvo minerala, kao što su kalcij, fosfor, magnezij, kalij, željezo, cink, bor i molibden, te da je bogata vitaminima $A, C, E$ i B-kompleksom. Osim toga, pšenična trava sadrži brojne

Sanja Grubišić, mag. ing. agr., Vedran Orkić, mag. ing. agr., Sunčica Guberac, mag. ing. agr., izv. prof. dr. sc. Sonja Petrović, izv. prof. dr. sc. Miroslav Lisjak, Marija Kristić, mag. ing. agr., izv. prof. dr. sc. Andrijana Rebekić (arebekic@fazos.hr) - Sveučilište Josipa Jurja Strossmayera u Osijeku, Fakultet agrobiotehničkih znanosti Osijek, Vladimira Preloga 1, 31000 Osijek, Hrvatska 
enzime (proteaza, amilaza, lipaza, superoksid dismutaza - SOD), svih devet esencijalnih aminokiselina te ima visok sadržaj bioflavonoida (Padalia i sur., 2010.) i kloroplastnih pigmenata. Visok sadržaj bioflavonoida (apigenin, kvercetin i luteolin) u pšeničnoj travi utječe na njezin antioksidativni kapacitet (Padalia i sur., 2010.). Bioflavonoidi ili flavonoidi su polifenolni spojevi biljnoga podrijetla koji djeluju protuupalno, antihepatotoksično i antiulkusno (Bors i sur., 1998.).

Antioksidativna aktivnost bioflavonoida ovisi o rasporedu funkcionalnih skupina unutar njihove nuklearne strukture. Mehanizam antioksidativnoga djelovanja bioflavonoida može uključivati: 1 . suzbijanje formacije reaktivne kisikove jedinke (reactive oxygen species - ROS) bilo inhibicijom enzima ili keliranjem elemenata u tragovima koji su uključeni u stvaranje slobodnih radikala, 2. uklanjanje reaktivnih kisikovih jedinki te 3. regulaciju ili zaštitu andioksidativne zaštite (Kumar i Pandey, 2013.).

$U$ soku pšenične trave uzgojene na otvorenome utvrđen je viši sadržaj klorofila nego u brokuli i kelju (Wakeham, 2013.). Klorofil je biljni pigment koji je uključen u fotosintezu. Kemijska struktura klorofila vrlo je slična kemijskoj strukturi hemoglobina, krvnoga pigmenta koji je odgovoran za transport kisika. Glavna razlika između kemijske strukture klorofila i hemoglobina jest u središnjem atomu pirolovih prstenova, koji u klorofilu sadrže magnezij, a u hemoglobinu željezo. Zbog sličnosti s hemoglobinom, klorofil ima blagotvoran učinak na ljudsko zdravlje, osobito u prevenciji i terapiji nedostataka hemoglobina (Wangcharoen i Phimphilai, 2016.). Osim toga, klorofil pomaže u detoksikaciji i smanjenju kiselosti u organizmu (Fahey i sur., 2005.). Sadržaj klorofila u pšeničnoj travi ovisi o načinu uzgoja, pri čemu intenzitet svjetlosti i trajanje uzgoja imaju najznačajniju ulogu.

Proteklih desetljeća terapijski učinak pšenične trave, kao i njezina učinkovitost u prevenciji bolesti, testiran je u brojnim istraživanjima. Visok sadržaj bioflavonoida u soku pšenice smanjuje rektalno krvarenje i bol u trbuhu kod bolesnika s ulceroznim kolitisom (Ben-Arye i sur., 2002.), pomaže u održavanju zdrave crijevne mikroflore, što pomaže poboljšanju probave i smanjenju bolesti probavnog sustava, ublažava simptome kroničnih bolesti i može olakšati terapiju bolesnicima u terminalnoj fazi brojnih malignih bolesti (Dey i sur., 2006.). Usto, sok pšenične trave ublažava simptome mijelotoksičnosti u bolesnica koje su podvrgnute kemoterapiji zbog oboljenja od karcinoma dojke bez smanjenja učinkovitosti kemoterapije (Bar-Sela i sur., 2007) te ima antiproliferativni učinak na stanične linije različitih humanih karcinoma (Gore i sur., 2006).

Zbog jednostavnosti uzgoja i jednostavne pripreme soka, pšenična trava se vrlo često uzgaja u kućanstvima. U takvim uvjetima uzgoja čest je problem pojava plijesni na supstratu i biljkama, što povećava mogućnost kontaminacije soka pšenične trave, a to ga čini nepogodnim za konzumaciju. Površinska dezinfekcija sjemena i dezinfekcija podloge na kojoj se uzgaja su mjere kojima se mogu uništiti patogeni mikroorganizmi i njihove spore. Do razvoja bolesti pšenične trave najčešće dolazi zbog zaraženosti sjemena. Stoga je dezinfekcija sjemena učinkovita preventivna mjera. Osim toga, prilikom dezinfekcije sjemena dolazi do omekšavanja membrane te samim time i do bržega klijanja. Nakon dezinfekcije sjeme se može odmah posijati ili se može staviti na naklijavanje. Naklijavanjem sjemena potiče se brže nicanje i rast pšenične trave. $S$ obzirom na navedeno, cilj istraživanja bio je ispitati razlike između načina dezinfekcije sjemena te vrste i načina dezinfekcije podloge za uzgoj pšenične trave koji se mogu primijeniti u kućanstvima glede pojave plijesni, broja i mase biljaka te količine soka u dvije sorte ozime pšenice (llirija i Katarina).

\section{MATERIJAL I METODE}

Istraživanje je provedeno na dvije sorte ozime pšenice (llirija i Katarina). Pokus je bio postavljen po potpuno slučajnom planu s tri tretmana (sorta: llirija i Katarina; dezinfekcija sjemena: destilirana voda, autoklavirana voda, 15\% NaClO; podloga: bez podloge, pijesak [dezinficiran i nedezinficiran], supstrat [dezinficiran i nedezinficiran]). Sjeme koje je korišteno u istraživanju nije tretirano prije skladištenje jer je čuvano u komori za čuvanje sjemena, pri temperaturi od $4^{\circ} \mathrm{C}$.

Dezinfekcija sjemena destiliranom i autoklaviranom vodom provedena je na isti način. Odvagano je $10 \mathrm{~g}$ sjemena te je sjeme stavljeno u teglice i preliveno destiliranom odnosno autoklaviranom vodom. Teglica sa sjemenom stavljena je na magnetnu miješalicu na kojoj je preliveno sjeme miješano pet minuta. Nakon isteka pet minuta voda je odlivena te je zrno ponovno preliveno destiliranom odnosno autoklaviranom vodom i stavljeno na magnetnu miješalicu u trajanju od pet minuta. Dezinfekcija sjemena s $15 \% \mathrm{NaClO}$ provedena je tako što je odvagano zrno preliveno s $15 \% \mathrm{NaClO}$ te miješano na magnetnoj miješalici 20 minuta. Nakon toga $\mathrm{NaClO}$ je odliven, a sjeme isprano autoklaviranom vodom miješanjem na magnetnoj miješalici tri puta po tri minute te još dva puta po pet minuta kako bi se sjeme što bolje ispralo. Nakon toga voda je odlivena $i$ sjeme stavljeno na naklijavanje u zatamnjenu prostoriju u trajanju od dva dana. Jedan dan nakon što je stavljeno na naklijavanje sjeme koje je dezinficirano destiliranom vodom još je jednom isprano destiliranom vodom, a sjeme koje je dezinficirano autoklaviranom vodom i 15\% $\mathrm{NaClO}$ isprano je autoklaviranom vodom.

Kao podloge za sjetvu korišteni su supstrat Bio start (Brill) i kvarcni pijesak (0,1-0,6 mm). Podloge su dezinficirane grijanjem u mikrovalnoj pećnici u trajanju od dvije minute. Dezinfekcija podloga je provedena dan prije sjetve kako bi se podloge u potpunosti ohladile.

$\mathrm{Na}$ dan sjetve plastične posudice promjera $10 \mathrm{~cm}$ napunjene su odgovarajućom podlogom i zalivene. $U$ svaku posudicu posijano je po 200 naklijalih zrna pšenice te je zrno prekriveno podlogom i zaliveno destiliranom vodom. U tretmanu bez podloge sjetva je obavljena u jednake posudice promjera $10 \mathrm{~cm}$ tako što je prebrojano 
200 naklijalih zrna i stavljeno direktno na dno prazne posudice. Posijane biljke su zalijevane svaki dan. Deseti dan nakon sjetve prebrojan je broj biljaka u posudici, odvagana je ukupna masa biljaka $(\mathrm{g})$ te je izmjerena količina soka pšenične trave $(\mathrm{ml})$, dobivenoga pomoću ručnog sokovnika za pšeničnu travu (Wheatgrass BL-30). Pojava i razvoj plijesni na podlozi ocijenjeni su opisnim ocjenama od 1 do 5.

Prikupljeni podatci statistički su obrađeni u programu SAS Enterprise Guide 7.1 (copyright (C) 2017 SAS Institut Inc., Cary, NC, USA). Utjecaj ispitivanih tretmana (sorta, podloga i način dezinfekcije sjemena) na istraživana svojstva utvrđen je faktorijalnom analizom varijance $(p<0,01)$. Razlike u broju i masi biljaka između pojedinih razina tretmana za koje je utvrđen statistički značajan utjecaj utvrđene su Tukeyevim post hoc testom (Tukey's HSD). Razlike u količini soka između sorata na svakoj podlozi pojedinačno su utvrđene t-testom $s$ jednim uzorkom (one-sample t-test). Za ispitivanje razlika između tretmana u pojavi plijesni korišten je Kruskal-Wallisov test.

\section{REZULTATI I RASPRAVA}

\section{Broj i masa biljaka}

U svaku posudicu bilo je posijano 200 naklijalih zrna pšenice, a deseti dan nakon sjetve izbrojane su i izvagane zdrave biljke. Broj biljaka po posudici bio je pod značajnim utjecajem sorte $(F=13,89 ; p<0,01)$, podloge $(F=41,62 ; p<0,01)$ i interakcije podloga $x$ dezinfekcija zrna $(F=3,59 ; p<0,01)$. Za način dezinfekcije zrna (autoklavirana voda, destilirana voda, $15 \% \mathrm{NaClO}$ ) nije utvrđen statistički značajan utjecaj na broj biljaka po posudici $(F=1,41, p<0,251)$.

Masa biljaka bila je pod značajnim utjecajem sorte $(F=151,63 ; p<0,01)$ i podloge $(F=139,02 ; p<0,01)$. Za razliku od broja biljaka koji je bio pod najvećim utjecajem podloge na kojoj su biljke uzgajane, masa biljaka je bila pod najvećim utjecajem sorte. Način dezinfekcije zrna (autoklavirana voda, destilirana voda, $15 \% \mathrm{NaClO}$ ) nije statistički značajno utjecao na masu biljaka $(F=0,92$, $\mathrm{p}<0,4031)$.

Najniži broj $(139 \pm 24)$ i najmanja prosječna masa biljaka $(6,14 \pm 2,78 \mathrm{~g})$, neovisno o sorti i načinu dezinfekcije zrna utvrđene su pri uzgoju bez podloge (Grafikon $1 \mathrm{i}$ Grafikon 2). Najveća razlika u prosječnome broju biljaka $(31 \%)$ utvrđena je između uzgoja bez podloge $(140 \pm 23)$ i uzgoja pšenične trave na dezinficiranome supstratu $(184 \pm 9,3)$ (Grafikon 1). Najniža prosječna masa biljaka također je utvrđena pri uzgoju bez podloge, i bila je tri puta niža nego prosječna masa biljaka pri uzgoju na dezinficiranome supstratu $(19,30 \pm 3,92 \mathrm{~g})$ (Grafikon 2). $\mathrm{U}$ odnosu na uzgoj na supstratu, prosječna masa biljaka uzgojenih na pijesku bila je niža za $40 \%$ (Grafikon 2).

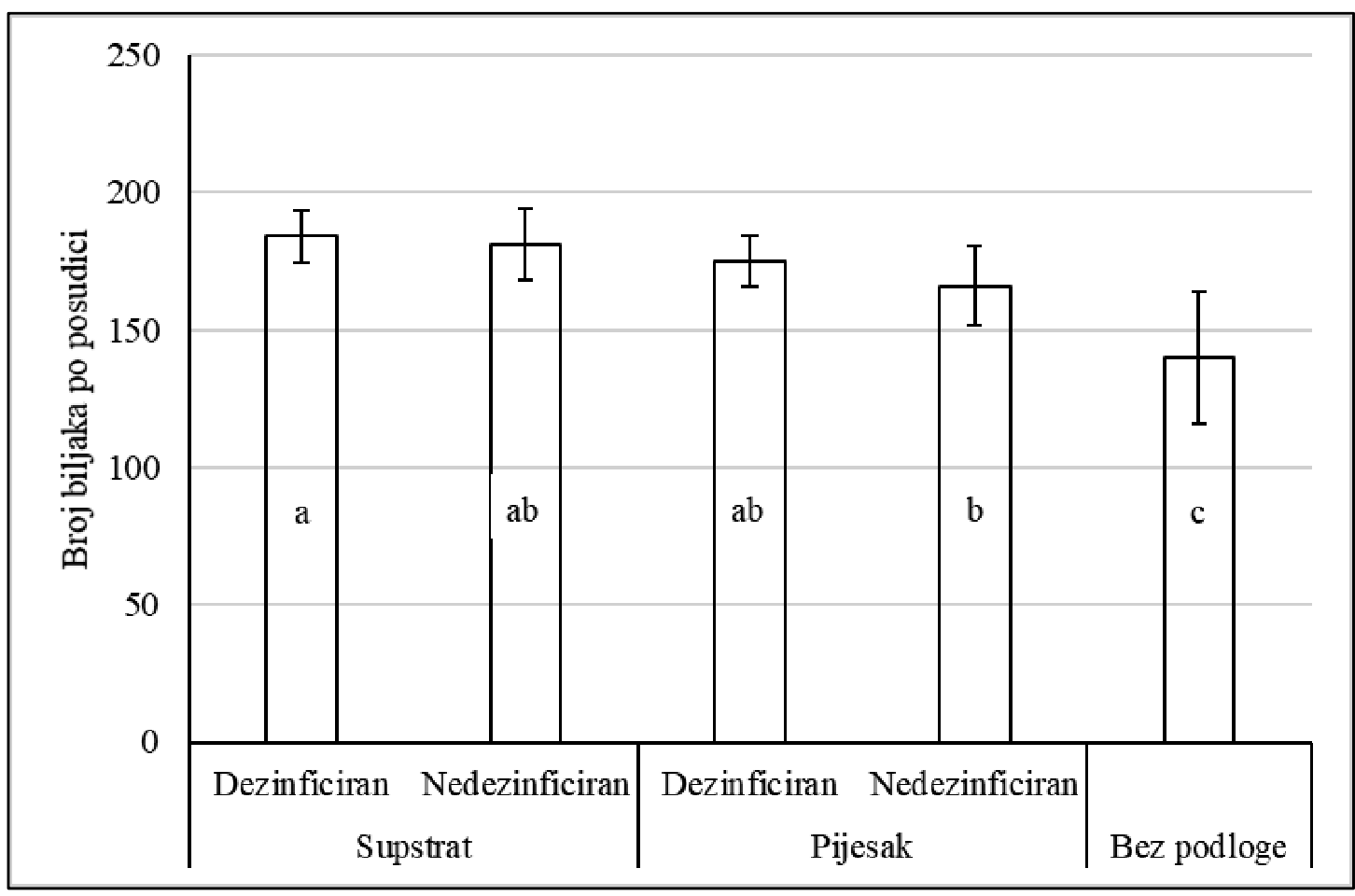

Grafikon 1. Prosječan broj biljaka po posudici pri uzgoju na različitim podlogama. Stupci označeni različitim slovima statistički se značajno razlikuju (Tukey HSD test; $p<0,01$ )

Figure 1. Average number of plants per pot grown on a different substratum. Different letters inside boxes indicate that groups differ by Tukey HSD test $(p<0.01)$ 
Općenito najveći broj biljaka i najveća masa biljaka $(\mathrm{g})$ utvrđene su pri uzgoju na supstratu (Grafikon 1 i Grafikon 2). U ovome istraživanju pšenična trava je uzgajana bez podloge zato što je na mnogim internetskim stranicama na kojima se daju upute kako uzgajati pšeničnu travu u kućnome uzgoju navedeno da se može uspješno uzgojiti bez podloge (https://www.wholesomesupplies.com.au/blogs/ fermenting-sprouting-blog/ how-to-grow-wheatgrass-without-soil - pristupljeno 27.05.2019.). Rezultati provedenoga istraživanja ukazuju na to da se uzgojem bez podloge dobije manji broj $\mathrm{i}$ manja masa biljaka u odnosu na uzgoj na pijesku i supstratu (Grafikon 1 i Grafikon 2).

Pri uzgoju pšenične trave bez podloge biljke su bile izložene većemu abiotičkom stresu nego biljke koje su uzgajane na supstratu ili pijesku. $U$ navedenome tretmanu biljke su uzgajane u plastičnim posudicama bez ikakve podloge. U takvome uzgoju voda kojom su biljke zalijevane zadržavala se na dnu posudice, tako da su zrno te kasnije i korijen dugo vremena bili u vodi, pri čemu je bilo otežano disanje, a samim time i apsorpcija i transport vode u nadzemne dijelove biljke. Rast biljaka u takvim uvjetima bio je otežan zbog postojanja anaerobnih uvjeta koji su doveli do ubrzanoga starenja listova te sporijega rasta nadzemnoga i podzemnog dijela biljke (Trought i Drew, 1980.) Osim toga, zbog maloga volumena posudica voda koju zrno nije apsorbiralo bi isparila, a nakon toga su biljke bile izložene sušnim uvjetima, prilikom kojih dolazi do odumiranja korijenskih dlačica (Lawlor, 1973.), što u konačnici rezultira smanjenjem apsorpcijske površine korijena. Prema tome, biljke koje su uzgajane bez podloge bile su izložene i uvjetima sušnoga stresa, što je rezultiralo slabijim porastom, manjim brojem biljaka i nedovoljno razvijenim korijenskim sustavom. Niža masa biljaka uzgojenih na pijesku u odnosu na masu biljaka uzgojenih na supstratu mogla bi biti posljedica lošijih vodozračnih odnosa i slijedom toga nastaloga sušnog stresa.

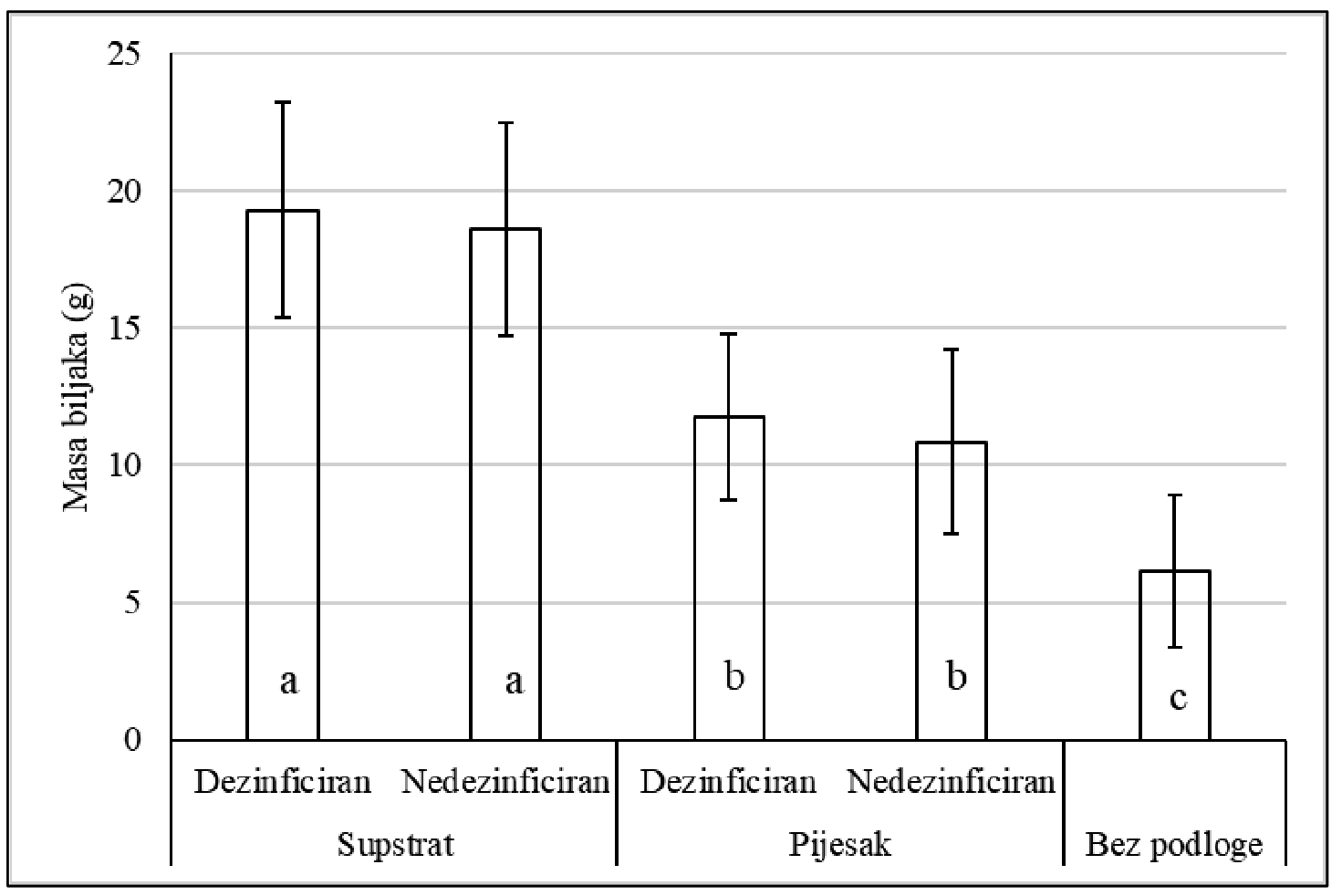

Grafikon 2. Prosječna masa biljaka po posudici (g) pri uzgoju na različitim podlogama. Stupci označeni različitim slovima statistički se značajno razlikuju (Tukey HSD test; $p<0,01$ )

Figure 2. Average plant weight (g) per pot grown on a different substratum. Different letters inside boxes indicate that groups differ by Tukey HSD test $(p<0.01)$

Od svih ispitivanih tretmana, sorta je imala najveći utjecaj na masu biljaka te su se ispitivane sorte značajno razlikovale po prosječnoj masi biljaka $(\mathrm{F}=147,6$; $\mathrm{df}=1$; $p<0,01)$. Sorta llirija imala je $48 \%$ veću prosječnu masu biljaka u odnosu na sortu Katarina. Osim toga, sorta Ilirija imala je veću prosječnu masu biljaka pri uzgoju na svim podlogama u odnosu na sortu Katarina (Tablica 1). Najveća razlika u masi biljaka između sorata $(87 \%)$ utvrđena je pri uzgoju bez podloge. Pri uzgoju na pijesku razlika u masi biljaka između sorata iznosila je 57 i $44 \%$ na nedezinficiranome i dezinficiranom pijesku te 42 i $41 \%$ na nedezinficiranome i dezinficiranom supstratu. 
Tablica 1. Prosječna masa biljaka po sortama (g) pri uzgoju na različitim podlogama (prosječna vrijednost \pm standardna devijacija). Prosječne vrijednosti sorata (u redu tablice) označene različitim slovima statistički se značajno razlikuju (Tukey HSD test; $\mathbf{p}<\mathbf{0 , 0 1}$ )

Table 1. Average cultivar plant weight (g) per pot grown on a different substratum (mean \pm standard deviation). Mean values with different letters inside row, indicate statistically significant difference by Tukey HSD test $(p<0.01)$

\begin{tabular}{|l|c|c|}
\hline Podloga - Substratum & llirija & Katarina \\
\hline Bez podloge (Without substratum) & $8,02 \pm 2,75 \mathrm{a}$ & $4,26 \pm 0,97 \mathrm{~b}$ \\
\hline Pijesak - ne dezinficiran (Sand - non disinfected) & $13,28 \pm 2,78 \mathrm{a}$ & $8,44 \pm 1,72 \mathrm{~b}$ \\
\hline Pijesak - dezinficiran (Sand - disinfected) & $13,89 \pm 1,94 \mathrm{a}$ & $9,64 \pm 2,38 \mathrm{~b}$ \\
\hline Supstrat - ne dezinficiran (Soil - non disinfected) & $21,89 \pm 2,03 \mathrm{a}$ & $15,36 \pm 2,00 \mathrm{~b}$ \\
\hline Supstrat - dezinficiran (Soil - disinfected) & $22,62 \pm 1,86 \mathrm{a}$ & $15,99 \pm 2,10 \mathrm{~b}$ \\
\hline
\end{tabular}

\section{Količina soka pšenične trave}

Pšenična trava koristi se kao dodatak prehrani u obliku svježega soka ili praha. Budući da se često uzgaja u kućanstvima i konzumira u obliku svježega soka, važno je za uzgoj izabrati sortu pšenice koja će dati što veću masu biljaka kako bismo dobili što veću količinu soka. U provedenome istraživanju masa biljaka $i$ količina soka su u pozitivnoj vezi $(r=0,98 ; p<0,01)$, što potvrđuje pretpostavku da će sorte koje imaju veću nadzemnu masu dati i veću količinu soka pšenične trave.

U tretmanu uzgoja pšenične trave bez podloge, zbog izrazito male mase biljaka nije bilo moguće ekstrahirati sok na ručnome sokovniku kojim smo se koristili za pripremu soka.

Od ispitivanih tretmana značajan utjecaj na količinu soka imaju sorta pšenice $(F=135,13, p<0,001)$, pri čemu je prosječna količina soka za sortu llirija iznosila $7,85 \pm 2,93 \mathrm{ml}$, a za sortu Katarina 5,08 $\pm 2,21 \mathrm{ml}$. 0sim toga, značajan utjecaj na količinu soka ima i podloga $(\mathrm{F}=101,31, p<0,001)$, dok način dezinfekcije sjemena nije imao statistički značajan utjecaj na količinu soka $(F=0,4, p<0,001)$. Usto, statistički značajne razlike $u$ količini soka između ispitivanih sorata utvrđene su na svim podlogama $(p<0.01)$. Obje sorte imale su veću količinu soka pri uzgoju na supstratu nego na pijesku (Tablica 2). U prosjeku, sorta llirija je pri uzgoju na supstratu imala 91, a sorta Katarina čak $115 \%$ veću količinu soka nego pri uzgoju na pijesku (Tablica 2). Prema tome, izbor podloge za uzgoj pšenične trave u kućnom uzgoju je vrlo značajan. Ovisno o podlozi, varirat će masa biljaka, a sukladno tome i količina dobivenoga soka.

Tablica 2. Količina soka pšenične trave po sortama (ml) pri uzgoju na različitim podlogama (prosječna vrijednost \pm standardna devijacija). Prosječne vrijednosti sorata (u redu tablice) označene različitim slovima statistički se značajno razlikuju (t - test; $\mathbf{p}<0.01$ )

Table 2. Average cultivar plant weight (g) per pot grown on a different substratum (mean \pm standard deviation). Mean values with different letters inside row, indicate statistically significant difference by One-sample $T$ test $(p<0.01)$

\begin{tabular}{|l|c|c|}
\hline Podloga - Substratum & llirija & Katarina \\
\hline Pijesak - nedezinficiran (Sand - non disinfected) & $5,23 \pm 1,31 \mathrm{a}$ & $3,03 \pm 1,06 \mathrm{~b}$ \\
\hline Pijesak - dezinficiran (Sand - disinfected) & $5,55 \pm 0,98 \mathrm{a}$ & $3,41 \pm 1,18 \mathrm{~b}$ \\
\hline Supstrat - nedezinficiran (Soil - non disinfected) & $10,46 \pm 1,51 \mathrm{a}$ & $6,89 \pm 1,01 \mathrm{~b}$ \\
\hline Supstrat - dezinficiran (Soil - disinfected) & $10,17 \pm 2,31 \mathrm{a}$ & $6,98 \pm 1,50 \mathrm{~b}$ \\
\hline
\end{tabular}

\section{Pojava plijesni na mladim listovima}

Pojava i razvoj plijesni u posudicama ocjenjeni su ocjenama od 1 do 5 . Navedene ocjene predstavljaju postotak pokrivenosti podloge plijesni (1 - 10-20\%; 2 - 20-40\%; 3 - 40-60\%; $4-60-80 \%$ i $5-80-100 \%$ ), koja je utvrđena prilikom uzorkovanja pšenice. KruskalWallisovim testom utvrđeno je da je značajan utjecaj na pojavu plijesni imala podloga na kojoj je pšenica uzgajana $\left(\chi^{2}=49,4 ; d f=4 ; p<0,01\right)$, pri čemu je najveća pojava plijesni utvrđena pri uzgoju bez podloge $(\bmod .=5 ;$ prosječna ocjena $=4,83)$, a najmanja pojava plijesni pri uzgoju na dezinficiranome $(\bmod =3$; prosječna ocjena $=2,17$ ) i nedezinficiranom supstratu (mod. $=1$ i 2; prosječna ocjena $=2,11$ ). Osim toga, statistički značajne razlike u pojavi plijesni utvrđene su između uzgoja pšenice bez podloge te dezinficiranog $(p=0,001)$ i nedezinficiranoga pijeska $(p=0,017)$, kao i između uzgoja bez podloge te dezinficiranoga $(p<0,001)$ i nedezinficiranog supstrata $(p<0,001)$. Kruskal-Wallisovim testom utvrđeno je da se ispitivane sorte nisu međusobno 
razlikovale po pojavi plijesni $\left(\chi^{2}=0,38 ; d f=1 ; p=0,53\right)$. Pojava plijesni na sve tri podloge je najvjerojatnije posljedica toga što sjeme nije bilo tretirano prije skladištenja. Pretpostavlja se da je povećana pojava plijesni u uzgoju pšenične trave bez podloge u odnosu na uzgoj na pijesku i supstratu posljedica lakšega prenošenja spora plijesni između zrna u posudici te lakše kontaminacije iz zraka. $S$ aspekta pripreme i konzumacije svježega soka pšenične trave, važno je napomenuti da je pojava plijesni zabilježena samo u posudicama, dok na listovima mlade pšenice nije bilo simptoma bolesti neovisno o načinu uzgoja.

\section{ZAKLJUČAK}

Pšenična trava se zbog svoje nutritivne vrijednosti sve češće koristi kao prirodni dodatak prehrani. Osim u obliku praha, koji je dostupan u trgovinama, često se konzumira u obliku svježega soka koji ljudi pripremaju od pšenične trave uzgajane u njihovim domovima. $S$ obzirom na to da uvjeti uzgoja značajno utječu na količinu i kvalitetu pripremljenoga soka važno je izabrati ogovarajuću sortu pšenice i odgovarajuću podlogu za uzgoj. Provedenim istraživanjem zaključeno je da sorta, u odnosu na ostale ispitivane tretmane, ima najveći utjecaj na broj i masu biljaka. U tome pogledu trebalo bi provesti istraživanje na većem broju sorata kako bi se detaljnije ispitale razlike između sorata s obzirom na masu i broj biljaka pri uzgoju pšenične trave. Masa biljaka je u pozitivnoj vezi s količinom soka, pa prema tome izbor sorte značajno utječe na količinu dobivenoga soka. Uzgoj bez podloge pokazao se najnepovoljnijim s obzirom na pojavu plijesni, te je preporuka koristiti se podlogom (supstratom) u uzgoju pšenične trave. Osim sorte i podloge, čiji je utjecaj ispitan u ovome istraživanju, veliki utjecaj na masu biljaka, količinu i kvalitetu soka te pojavu plijesni imaju i uvjeti uzgoja kao što su temperatura i vlaga zraka, jačina osvjetljenja, režim dan-noć te broj dana uzgoja, što su faktori koje treba ispitati kako bi se utvrdili idealni uvjeti uzgoja pšenice za pripremu soka pšenične trave u kućanstvima.

\section{ZAHVALA}

Ovo istraživanje financirala je Hrvatska zaklada za znanost u sklopu projekta UIP-2017-05-4292.

\section{LITERATURA}

1. Bar-Sela, G., Tsalic, M., Fried, G., \& Goldberg, H. (2007). Wheat grass juice may improve hematological toxicity related to chemotherapy in breast cancer patients: a pilot study. Nutrition and cancer, 58(1), 43-48.

2. Ben-Arye, E., Goldin, E., Wengrower, D., Stamper, A., Kohn, R., \& Berry, E. (2002). Wheat grass juice in the treatment of active distal ulcerative colitis: a randomized double-blind placebo-controlled trial. Scandinavian Journal of Gastroenterology, 37(4), 444-449.
3. Bors, W., Heller, W., \& Michael, M. (1998). Flavonoids as antioxidants: determination of radical scavenging efficiencies. Methods in Enzymology, 186, 343-355. https://doi.org/10.1016/0076-6879(90)86128-I

4. Devi Sowjanya, K., Hariprasath, K., Nalini, G. R., Veenaeesh, P., \& Ravichandra, S. (2015). Wheat grass juice-Triticum aestivum Linn'a therapeutic tool in pharmaceutical research, an overview. International Journal of Pharmacy and Pharmaceutical Research, 3(3), 112 121.

5. Dey, S., Sarkar, R., Ghosh, P., Khatun, R., Ghorai, K., Choudhury, R., \& Mukhopadhyay, A. (2006). Effect of wheat grass juice in supportive care of terminally ill cancer patients - a tertiary cancer centre experience from India. Journal of Clinical Oncology, 24(18_suppl), 8634-8634.

https://doi.org/10.1200/jco.2006.24.18_suppl.8634

6. Fahey, J. W., Stephenson, K. K., Dinkova-Kostova, A. T., Egner, P. A., Kensler, T. W., \& Talalay, P. (2005). Chlorophyll, chlorophyllin and related tetrapyrroles are significant inducers of mammalian phase 2 cytoprotective genes. Carcinogenesis, 26(7), 1247-1255. https://doi.org/10.1093/carcin/bgi068

7. Gore, R. D., Palaskar, S. J., \& Bartake, A. R. (2017). Wheatgrass: green blood can help to fight Cancer. Journal of Clinical and Diagnostic Research, 11(6), ZC40ZC42. https://doi.org/10.7860/JCDR/2017/26316.10057

8. Kumar, S., \& Pandey, A. K. (2013). Chemistry and biological activities of flavonoids: an overview. The Scientific World Journal, Article ID 162750, 16 pages. https://dx.doi.org/10.1155/2013/162750

9. Lawlor, D. W. (1973). Growth and water absorption of wheat with parts of the roots at different water potentials. New Phytologist, 72(2), 297-305.

10. Padalia, S., Drabu, S., Raheja, I., Gupta, A., \& Dhamija, M. (2010). Multitude potential of wheatgrass juice (Green Blood): An overview. Chronicles of Young Scientists, 1(2), 23.

11. Trought, M. C. T., \& Drew, M. C. (1980). The development of waterlogging damage in young wheat plants in anaerobic solution cultures. Journal of Experimental Botany, 31(6), 1573-1585.

12. Wakeham, P. (2013). The medicinal and pharmacological screening of wheatgrass juice (Triticum aestivum L.): an investigation into chlorophyll content and antimicrobial activity. The Plymouth Student Scientist, 6(2), 20-30.

13. Wangcharoen, W., \& Phimphilai, S. (2016). Chlorophyll and total phenolic contents, antioxidant activities and consumer acceptance test of processed grass drinks. Journal of Food Science and Technology, 53(12), 41354140. https://doi.org/10.1007/s13197-016-2380-z

14. Wigmore, A. The wheatgrass book: How to grow and use wheatgrass to maximize your health and vitality. 1985, USA: Ann Wigmore and the Hippocrates Health Institute, Inc. 


\section{OPTIMAL METHOD OF SOWING WHEAT (Triticum aestivum L.) FOR GROWING WHEATGRASS}

\section{SUMMARY}

Wheatgrass represents wheat plants in the early stage of development, prior to the jointing stage. Due to its high concentration of minerals, vitamins, enzymes, chlorophyll, and bioflavonoids, wheatgrass is commonly used as a natural dietary supplement. Although it can be consumed in the form of powder or tablets, it is often consumed in the form of fresh juice, which is why wheatgrass is grown in households. The main problem in such cultivation is the occurrence of mildew on plants and substrate. Therefore, the aim of this study was to investigate the differences in surface disinfection of seeds and the type and disinfection of substrate (no substrate, disinfected/non-disinfected quartz sand and disinfected/non-disinfected Brill substrate) on the incidence of mildew, the number of plants, plant weight $(\mathrm{g})$ and the amount of juice obtained $(\mathrm{ml})$ in two wheat cultivars (Ilirija and Katarina). The methods of seed-surface disinfection and substrate disinfection tested in this research can be applied in households. The highest number of plants per pot and highest average plant weight were determined on Brill substrate, regardless of wheat cultivar. A positive correlation was found between plant weight and the amount of juice obtained $(r=0.98 ; p<0.01)$. An average amount of juice for cultivar Ilirija was $7.85 \pm 2.93 \mathrm{ml}$, while cultivar Katarina had an average of $5.08 \pm 2.21 \mathrm{ml}$ of juice. The highest incidence of mildew was detected in wheatgrass cultivation without substrate. The obtained results indicate that the examined traits are under the strongest influence of cultivar and the type of substrate.

Keywords: wheatgrass, seed disinfection, growing conditions

(Primljeno 15. rujna 2019.; prihvaćeno 23. listopada 2019. - Received on September 15, 2019; accepted on October $23,2019)$ 